Crime, Histoire \& Sociétés / Crime, History \& Societies

Vol. 21, n² | 2017

L'histoire de la criminalité et de la justice pénale : propositions de recherche pour le $21^{\mathrm{e}}$ siècle

\title{
Future Agendas for the Study of International Crime
}

Paul Knepper

\section{(2) OpenEdition Journals}

Electronic version

URL: http://journals.openedition.org/chs/1838

DOI: $10.4000 /$ chs. 1838

ISSN: 1663-4837

\section{Publisher}

Librairie Droz

\section{Printed version}

Date of publication: 31 December 2017

Number of pages: 135-142

ISSN: 1422-0857

\section{Electronic reference}

Paul Knepper, "Future Agendas for the Study of International Crime", Crime, Histoire \& Sociétés / Crime, History \& Societies [Online], Vol. 21, $n^{\circ} 2$ | 2017, Online since 19 July 2020, connection on 16 January 2021. URL: http://journals.openedition.org/chs/1838 ; DOI: https://doi.org/10.4000/chs.1838 


\title{
Future Agendas for the Study of International Crime
}

\author{
Paul Knepper
}

$\mathrm{M}$ ost of the history of crime has been written on a small scale. Historians have examined developments within a single country, often at the level of counties and cities ${ }^{1}$. However, the history of international crime has started to appear, including studies of the white slave trade, anarchist violence and drug smuggling.

International crime is a particularly important topic for historians. Criminologists and other social scientists suggest that we are currently living at the end of one age and the beginning of another claiming, variously, that we are entering the "postmodern era", the "information society", the "pre-crime society" or the "globalization era". In this emerging period of history, crime has significance it has not before. New threats, such as trafficking, terrorism and cybercrime, have emerged as particular foci of concern with the rise of the internet and in the aftermath of $911^{2}$. But, as any historian knows, periodization of time is fraught with methodological complexities. To understand what is novel about our own time, we need an understanding of the past.

Writing the history of international crime is unlike other kinds of crime history in two ways. The first, methodological, and the second, theoretical. The leading sources of evidence, court records and crime statistics, are not available for international crime. Because of the lack of "data", social science techniques, such as comparing crime rates, do not work. There is also the challenge of how to frame and interpret activities known as "international crime". Given that much crime history has been written at the national or urban level, the temptation has been to simply scale up explanations across borders. But we should not assume that concepts for explaining criminal activity at a local level can be stretched to a global level.

In this essay, I will review the research into human trafficking, terrorism and drugs across three periods of history: late nineteenth century, interwar years, and post-war. I will discuss some recent research, including work by $\mathrm{PhD}$ students. My aim will be to identify questions related to sources and theories to be addressed in the future. In conclusion, I will return to the question about our own future and the value of historical perspective in understanding our own time.

\footnotetext{
$1 \quad$ Emsley (2007, p.1).

2 Garland and Sparks (2001); Zedner (2007); van Schendel and Abraham (2005). 


\section{LATE NINETEENTH CENTURY}

To unravel the challenges of recovering international crime in the past, the white slave trade is a good place to start. The movement began to cause international concern in the late nineteenth century and campaigners urged governments to take action and established international anti-traffic organizations. Of all the topics and time periods pertinent to the study of international crime, the white slave trade has generated the most historiography, and the questions that have been raised apply to other topics, including the drug traffic and anarchist violence.

In 2015, Julia Laite organized a symposium at Birkbeck Institute for the Humanities in London that brought together leading researchers. "Trafficking, Smuggling and Illicit Migration in Historical Perspective" included Petra de Vries, who has written about the Dutch campaign; Jessica Pliley, who has written about the FBI and the American campaign; and Pamela Cox, who has written about trafficking and the sex trade in London ${ }^{3}$. Based on her work in Russian archives, Philippa Hetherington initiated discussion by posing the question: To what extent is it possible to get beyond the concerns of campaigners and find the views of trafficked women? To recover the lives of trafficking victims remains a challenge since virtually everything we "know" about their experiences comes from those intent on saving them. Campaigners brought different motivations to their project, and sought to use the experiences of trafficked women for various purposes.

Getting beyond the views of campaigners is important, because it allows us to address a puzzling question that has yet to find an answer: Was the campaign against the white slave trade solely a "scare" or "panic" that existed in public imagination, or was it a real problem that emerged for the first time in the late nineteenth century? I realize this is a philosophical question. From Foucault's point of view, there is only narrative and we can never really "tell it like it was" anyway. But, to the extent we can find materials, we can tell it more from the view of the victims rather than the campaigners, and this victims' perspective will help explain what was going on.

Although leading anarchist thinkers wrote a great deal, anarchist violence presents a similar question. The International Institute for Social History at Amsterdam contains papers of leading anarchists, which inform us about the movement. But we know far less about those who perpetrated violence in the name of anarchist causes. Wouter Klem at Utrecht University is researching the anti-anarchism campaign between 1815 and 1914. His research focuses on transnational police networks, including contacts between police officials and the diffusion of technologies. He presented some of this work at the 2016 European Social Science History Conference in Valencia. His paper dealt with the ways Dutch police framed the foreign anarchist threat in order to convince the Ministry of Justice to implement new security measures. This is important research because much of the historical record consists of the "police view" of anarchist violence, and it requires some effort to get beyond this. Digital archives are increasingly becoming available, including vast collections of newspaper material. This material lends itself toward "panic" or "scare" aspects - images of foreign men with dark skins and even darker hearts. But this material is much less useful for drilling down to the emotions and experiences of victimized women. To do so requires the far less convenient microhistory route. Charles Van Onselen's

de Vries (2005); Pliley (2014). 
biography of Joseph Silver tracks an international criminal - Silver was engaged in human traffic, drugs, theft, racketeering - over 50 years from Europe to the USA, to South Africa, South America and back. In an appendix, "Clio and the Fox: The Hunt for Joseph Silver and His Hidden Pasts", he explains how he pieced together Silver's life of crime from documents scattered across archives in various countries. This research reveals networks of smugglers and victims, police and informers that animated the world of cross-border criminality and criminal justice ${ }^{4}$.

\section{INTERWAR PERIOD}

Compared to the nineteenth century, the interwar period has hitherto attracted less interest, although this is beginning to change. There is a growing interest in the 1920s and 1930s and the significance of international crime in the decades after the First World War and the beginning of the Second World War. David Petruccelli has produced some interesting work. His $\mathrm{PhD}$ research at Yale looked into the internationalization of criminal police work, particularly the ambitions of the International Criminal Police Commission during the interwar period ${ }^{5} \mathrm{He}$ looked into how certain activities across borders, such as trafficking in human beings and drugs, counterfeiting in currency and passports, and the threat of certain mobile groups were criminalized, and how this altered policing practices ${ }^{6}$.

As is the case in the nineteenth century, the usual "data" for crime history is hard to locate, but the League of Nations produced a significant amount of useful information. The League of Nations created the modern language of international crime, replacing white slave trade with "traffic in women" and anarchist outrage with "terrorism". The League also introduced the intergovernmental machinery for prohibiting drugs, investigating traffic in women, and countering terrorism that would define international crime prevention during the twentieth century. In addition to the League of Nations archives, at the United Nations Office in Geneva, there are documents of organizations that worked with the League. The archives of the Howard League, at the University of Warwick, contain useful material about various international projects. The Howard League was one of several organizations that became official advisors the League of Nations' committees on crime and criminal justice related activities.

Magaly Rodríguez García organized a symposium in 2013 at the Palais des Nations covering the work of the League on social issues. The symposium included presentations on cannabis policy, regulated brothels, the trafficking investigation and other topics? ${ }^{7}$. The symposium examined important questions, starting with language. Although the language of the symposium was English, much of the work of the League, as Sandrine Kott observed, appears in French. In addition, important historiography also appears in French. Jean-Michel Chaumont's Le mythe de la traite des blanches is the

van Onselen (2007).

Petruccelli (2015a)

Petruccelli (2015b).

Garcia et al. (2016). 
leading analysis of the League's investigation into the traffic in women during the $1920 \mathrm{~s}^{8}$. One of the most exciting developments in international crime history is the number of early career researchers bringing materials to English readers from French, German, Spanish, Russian and other sources. Eva Payne, who is completing a $\mathrm{PhD}$ in American Studies at Harvard University, is using her knowledge of French and Spanish to interrogate issues of gender, migration and the sex trade between France and South America.

The League tried to quantify drug smuggling. There are annual reports from member states and a large collection of police reports of thieves, fraudsters, pimps and other travelling rogues. If this information were systematically analyzed, it would shine some light on the dark figure of international crime, although it does represent a tricky source. In response to the League's investigation into the traffic in women, various governments began collecting information. In annual reports prepared by the chief of police in Malta, for example, there are new cases of traffic in women in the 1920s, or, at least new references. It is difficult to know whether these cases have been detected now that the League has raised the visibility of the problem, or whether the police simply refer to some of the same old prostitution cases under the new language of trafficking.

There is also an interpretation issue related to organized crime. The League's interest in crime coincided with the gangster era in Chicago (and Hollywood), and conceptions of the "underworld" appear in discussions of trafficking. The "gangster theory" presents international crime as an illegitimate form of economic enterprise and those involved form networks analogous to business associates. Gangsters appear in the shadows of urbanization. Historians should be cautious about adopting this perspective. It is easy to imagine crime as a local phenomenon at some point in the past, and that becomes more global with advances in transportation, communication and commerce. But there is a problem of scale. Organizations that function in neighborhoods do not operate the same way, if at all, across oceans and continents. Mark Haller, who wrote about organized crime in Chicago, emphasized the underworld as a small-scale, less-than-organized form of business 9 .

The role of ethnic minority populations and women presents important areas for further inquiry. The League's reports emphasize the role of Jews in the traffic in both women and drugs. Some historians, such as Alan Block, simply take the League at its word and rely on the League's materials as documentary sources ${ }^{10}$ But we know from Chaumont's work that the League's investigation inadvertently emphasized Jewish involvement. As he explains, the League's premiere investigator was Jewish and used his knowledge of Yiddish to explore the Jewish underworld of major cities. We also know that the Nazis exaggerated the threat of organized crime in general, and "Jewish trafficking" in particular, for their own purposes" .

Judith Walkowitz proposed that the white slave trade appeared in the nineteenth century as a counter-movement to the early women's movement ${ }^{12}$. The alarmists

\footnotetext{
Chaumont (2009).

Yeager (2012).

Block (1989).

Goeschel (2013).

12 Walkowitz (1992).
} 
hoped fear of being snatched by a white slave trader would send women back into the private, domestic sphere. The League could be seen as an exercise in masculine hegemony as well. The League's drug control committee has been described as a "gentlemen's club" in which a small group of men thought they could decide drug policy for the remainder of the world's inhabitants ${ }^{13}$. But, the League opened up public space for women in leadership not afforded by national governments, and would not have taken up the trafficking issue were it not for early feminist organizations. Stephanie Limoncelli explores the response to trafficking within the women's movement including disagreement between the moral purists and feminists ${ }^{14}$.

\section{LATE TWENTIETH CENTURY}

Moving into the second half of the nineteenth century, the task becomes more difficult. In 1947, the Economic and Social Council of the United Nations (UN) announced its intention to assume leadership in responding to crime. The UN applied itself a wide array of crime and criminal justice activities, including international crime, referred to as "transnational crime" from the 1970s. UN interest has produced thousands of documents and the mass of material at the UN libraries in New York and Geneva can be intimidating even to the most experienced archival researcher. The "good news" - from the standpoint of contemplating where to begin - is that most of this material is quite useless for historical research. Most are aspirational statements screened through diplomatic filters precisely to remove all traces of the ingredients that went into creating them.

There are some "histories" by international lawyers which provide chronological summaries of this material, but do they do not address wider historiography of crime $^{15}$. There are also memoirs, reminiscences, and accounts written by former diplomats which offer some insights not found in the official documents, although these have their limitations as well ${ }^{16}$. These fall into the category of internal or institutional histories that avoid wider social, economic, cultural and political trends. To address historical questions concerning the UN, historians should extend their investigation to collections of personal papers. The University of Pennsylvania holds materials left by Thorsten Sellin and Florida State University has materials by Leon Radzinowicz. Sellin led or participated in various United Nations panels of experts on criminological questions over several decades. Radzinowicz served as the first chief of the UN Section on Social Defense, organized the UN Conference on Crime Prevention in London in 1960, and as a consultant to the UN on several crime prevention projects.

During the 1930s, the International Penal and Penitentiary Commission (IPPC) fell under control of the Nazis. The Berlin congress of 1935 celebrated Hitler's crime reduction policies. When the UN set up its crime prevention program, the decision

\footnotetext{
13 Bruun et al. (1975).

14 Limoncelli (2010).

15 See, for example, Clark (1994).

16 Such as Alper and Boren (1972).
} 
was made to liquidate the IPPC as an organization, but continue to pursue its activities. Sellin, the last director of the IPPC and a member of the first International Group of Experts on the Prevention of Crime and Treatment of Offenders at the UN, said the decision resulted from a "smear campaign"17. But it is unclear what happened - and what role Sellin had in the liquidation - because it is precisely the sort of thing not found in UN documents.

One of the things that becomes clear when reviewing the UN approach is the extent of continuity with the past. The UN inherited the League's conceptual language of trafficking and its organizational structure of working with advisory organizations. Despite the rhetoric of diplomats about epoch-making events, the story is about incremental change and continuity with the past. Trafficking in drugs and women, which had been the work of the technical committees within the League, became organizations within the UN. The UN absorbed the functions of the IPPC and carried on the conference program the IPPC had organized from the nineteenth century.

The UN certainly had a role in circulating policies and approaches to crime, not only cross-border activities but also domestic issues such as juvenile delinquency. The UN established criminological institutes in world regions and sent technical experts to various places to promote research into crime. Israel Drapkin, the founding director of the Institute of Criminology and the Hebrew University, originally came to Jerusalem as a UN technical expert. But, reading the proceedings of congresses, resolutions of committees, and reports by consultants, it is easy to misunderstand the formation of international crime policy and diffusion of criminal justice institutions. Frank Dikötter brings a useful perspective on this process from his study of the "global prison", the adoption of prison as the primary sanction in countries throughout the world. The ubiquity of prisons did not result from the plans of internationalists whether the IPPC, League, or UN. Rather, it was an invention adapted and reinvented by local governments. Local elites around the world chose to build prisons to associate themselves with the views of Enlightened philosophies and the institutions of advanced nations ${ }^{18}$.

There are internationalists who believe in common solutions to problems. The UN attracted dreamers, visionaries and reformers that firmly believed in the existence of global problems and that such problems could only be solved through multinational efforts. Mark Mazower traces the history of this idea since the Concert of Europe in $1815^{19}$. But there are those who readily joined into international policies, not to pursue a global vision, but to advance much more parochial agendas. Politicians used international forums to champion projects close to home and gain leverage over local rivals.

\section{CONCLUSIONS}

Finally, a comment on the present age of international crime. The new millennium has inspired criminologists, as well as social scientists across many fields, to reflect on changes ahead. Citing the rise of the internet, criminologists foresee a new era of

\footnotetext{
17 Selling (1964, p.199).

18 Dikötter (2007).

19 Mazower (2012).
} 
international crime. Cybercrime presents a new frontier, a larger and more threatening crime problem than ever before.

From a historical perspective, cybercrime looks rather different. As Tom Standage points out, the first generation to experience crime committed in virtual space lived in the nineteenth century. The telegraph - "the Victorian internet" - provided for instantaneous communication, revolutionized business, challenged government regulation, and afford new opportunities for fraud, theft, and deception. "The equipment may have been different", Standage observes, "but the telegraph's impact on the lives of its users was strikingly similar" ${ }^{\prime 20}$. For historians and criminologists interested in international crime, he offers a warning against "chronocentricity", the tendency to believe that one's own generation is at a pivotal moment in history.

David Wall explains that much of the current language of cybercrime originated in science fiction of the 1970s and $1980 \mathrm{~s}^{21}$. Novels promoted dystopic visions about life in virtual space and films portrayed hackers with the power to disrupt people's live on a massive scale. He points out that the threat was neither new nor novel. The image of the cybercriminal, the most advanced form of international criminal today, originates in Victorian science fiction with characters that constructed or appropriated technology to gain power over others.

Paul Knepper

Professor of Criminology

Department of Law and Justice

Central Western University

Ellensburg, WA, USA

paul.knepper@cwu.edu

\section{BIBLIOGRAPHY}

Alper, B. and Boren, J. (1972) Crime: International Agenda. Concern and Action in the Prevention of Crime and Treatment of Offenders, 1846-1972, Lexington, MA: DC Heath.

Block, A. (1989) European Drug Traffic and Traffickers between the wars: The policy of suppression and its consequences, Journal of Social History, 23, p.315-337.

Bruun, K., Pan, L., and Rexed, I. (1975) The Gentlemen's Club: International Control of Drugs and Alcohol, Chicago: University of Chicago Press.

Chaumont, J.M. (2009) Le mythe de la traite des blanches. Enquête sur la fabrication d'un fléau, Paris: La Découverte.

Clark, R. (1994) The United Nations Crime Prevention and Criminal Justice Program: Formulation of Standards and their Implementation, Philadelphia: University of Pennsylvania Press.

De Vries, P. (2005) White Slaves' in a Colonial nation: the Dutch Campaign against the Traffic in Women in the Early Twentieth Century, Social and Legal Studies, 14, 1, p.39-60.

Dikötter, F. (2007) Introduction, in Dikötter, F. and Brown, I. (Eds.), Cultures of Confinement: A History of the Prison in Africa, Asia and Latin America, Ithaca, NY: Cornell University Press.

20 Standage (1998, p.2).

21 Wall (2011). 
Emsley, C. (2007) Crime, Police, and Penal Policy: European Experiences 1750-1940, Oxford: Oxford University Press.

Garcia, M., Rodogno, D., and Kozma, L., Eds., (2016) The League of Nations' Work on Social Issues: Visions, Endeavours and Experiments, Geneva: United Nations Office.

Garland, D. and Sparks, R. (2001) Criminology, social theory and the challenge of our times, British Journal of Criminology, 40, p.189-204.

Goeschel, C. (2013) The criminal underworld in Weimar and Nazi Berlin, History Workshop Journal, 75, p.1-13.

Limoncelli, S. (2010) The Politics of Trafficking: The First International Movement to Combat the Sexual Exploitation of Women, Stanford: Stanford University Press.

Mazower, M. (2012) Governing the World: The History of an Idea, New York: Penguin.

Petruccelli, D. (2015a) A Scourge of Humanity: International crime and Policing in Interwar Europe, unpub. PhD thesis, Yale University.

Petruccelli, D. (2015b) Pimps, Prostitutes and Policewomen: The Polish Women Police and the International Campaign against the Traffic in Women and Children between the World Wars, Contemporary European History, 24, 3, p.333-350.

Pliley, J. (2014) Policing Sexuality: The Mann Act and the Making of the FBI, Cambridge, MA: Harvard University Press.

Sellin, T. (1964) Lionel Fox and the International Penal and Penitentiary Commission, in Lopez-Ray, M. and Germain, C. (Eds.) Studies in Penology, The Hague: Martinus Nijhoff, p. 194-207.

Standage, T. (1998) The Victorian Internet: The Remarkable Story of the Telegraph and the Nineteenth Century's Online Pioneers, London: Weidenfeld \& Nicolson.

Van Onselen, C. (2007) The Fox and the Flies: The World of Joseph Silver, Racketeer and Psychopath, London: Jonathan Cape.

Van Schendel, W. and Abraham, I. (2005) Illicit Flows and Criminal Things: States, Borders and the Other Side of Globalization, Bloomington, IN: Indiana University Press.

Wall, D. (2011) Cybercrime and the culture of fear: Social science fiction(s) and the production of knowledge about cybercrime, Information, Communication \& Society, 11, p. 861-884.

Walkowitz, J. (1992) City of Dreadful Delight: Narratives of Sexual danger in Late-Victorian London, Chicago: University of Chicago Press.

Yeager, M. (2012) Fifty years of research on illegal enterprises: An interview with Mark Haller, Trends in Organized Crime, 15, p.1-12.

Zedner, L. (2007) Pre-crime and post-criminology? Theoretical Criminology, 11, p. 261-281. 